\title{
Transforming growth factor- $\beta$ suppresses metastasis in a subset of human colon carcinoma cells
}

\author{
Neka A. K. Simms ${ }^{1 \dagger}$, Ashwani Rajput ${ }^{2 \dagger}$, Elizabeth A Sharratt ${ }^{3}$, Melanie Ongchin ${ }^{4}$, Carol A Teggart ${ }^{1}$, Jing Wang ${ }^{1}$ \\ and Michael G Brattain ${ }^{1 *}$
}

\begin{abstract}
Background: TGF $\beta$ signaling has typically been associated with suppression of tumor initiation while the role it plays in metastasis is generally associated with progression of malignancy. However, we present evidence here for an anti-metastatic role of TGF $\beta$ signaling.

Methods: To test the importance of TGF $\beta$ signaling to cell survival and metastasis we compared human colon carcinoma cell lines that are either non-tumorigenic with TGF $\beta$ response (FET), or tumorigenic with TGF $\beta$ response (FETa) or tumorigenic with abrogated TGF $\beta$ response via introduction of dominant negative TGF $\beta R I I$ (FETa/DN) and their ability to metastasize. Metastatic competency was assessed by orthotopic transplantation. Metastatic colony formation was assessed histologically and by imaging.

Results: Abrogation of TGF $\beta$ signaling through introduction of a dominant negative TGF $\beta$ receptor II (TGF $\beta$ RII) in non-metastatic FETa human colon cancer cells permits metastasis to distal organs, but importantly does not reduce invasive behavior at the primary site. Loss of TGF $\beta$ signaling in FETa-DN cells generated enhanced cell survival capabilities in response to cellular stress in vitro. We show that enhanced cellular survival is associated with increased AKT phosphorylation and cytoplasmic expression of inhibitor of apoptosis (IAP) family members (survivin and XIAP) that elicit a cytoprotective effect through inhibition of caspases in response to stress. To confirm that TGF $\beta$ signaling is a metastasis suppressor, we rescued TGF $\beta$ signaling in CBS metastatic colon cancer cells that had lost TGF $\beta$ receptor expression due to epigenetic repression. Restoration of TGF $\beta$ signaling resulted in the inhibition of metastatic colony formation in distal organs by these cells. These results indicate that TGF $\beta$ signaling has an important role in the suppression of metastatic potential in tumors that have already progressed to the stage of an invasive carcinoma.

Conclusions: The observations presented here indicate a metastasis suppressor role for TGF $\beta$ signaling in human colon cancer cells. This raises the concern that therapies targeting inhibition of TGF $\beta$ signaling may be imprudent in some patient populations with residual TGF $\beta$ tumor suppressor activity.
\end{abstract}

\section{Background}

Metastatic disease accounts for $90 \%$ of cancer related deaths in all cancers [1]. The metastatic process requires the ability of the tumor to invade at the primary site, undergo intravasation, survive immune surveillance in blood circulation, undergo extravasation at a distal organ

\footnotetext{
*Correspondence: mbrattain@unmc.edu

${ }^{\dagger}$ Equal contributors

'Eppley Institute for Research in Cancer and Allied Diseases, University at Nebraska Medical Center, Omaha, USA

Full list of author information is available at the end of the article
}

site and form new colonies at this secondary organ site [2]. Molecular mechanisms involved in the establishment of metastases are largely unknown. Understanding molecular mechanisms involved in the metastatic process could identify novel potential targets for development of more effective therapeutic intervention against established metastatic disease.

An important aspect of metastatic potential is the ability of a cancer cell to evade apoptotic signals under stress conditions which could normally lead to cell death $[3,4]$. Evasion of apoptosis can occur as a result of loss

\section{() Biomed Central}


of tumor suppressor activity and/or enhanced oncogenic activity thus shifting the balance of stress response toward inappropriate cell survival. Many cellular pathways have been linked to enhanced survival or anti-apoptotic signaling and malignant progression; here we investigated the role of transforming growth factor- $\beta$ (TGF $\beta$ ) in an orthotopic colorectal cancer model of metastasis.

The general consensus is that TGF $\beta$ signaling is tumor suppressive in early carcinogenesis, but it becomes tumor promoting during later stages of cancer [5]. TGF $\beta$ signaling through Smad activation is regarded as tumor suppressive during the early stages of cancer and precancerous lesions as it has been shown that loss of TGF $\beta$ tumor suppressor signaling has been associated with tumor initiation and progression of several types of tumors including colon cancer. TGFßRII has been shown to be inactivated by mutation in human colon cancers with microsatellite instability [6]. Other types of cancer as well as some subsets of colon cancer are often associated with epigenetic transcriptional repression of TGF $\beta$ receptors rather than mutational inactivation of the pathway [7-9], ultimately contributing to a loss in growth control as well as resistance to apoptosis [10,11]. Studies conducted in breast cancer demonstrated that the unmodified transcription factor $\mathrm{Sp} 3$ induces transcriptional repression of TGF $\beta$ RII promoter [7]; consequently, treatment with histone deacetylase inhibitor, Trichostatin A (TSA), results in acetylated Sp3 which alleviates transcriptional repression of TGF $\beta$ RII gene expression [8]. On the other hand, it has been reported that increased expression of receptor ligands by tumor cells was associated with tumor progression in nonsmall cell lung cancer (NSCLC), colorectal cancer and gastric carcinomas [12-14]. Thus, one view is that TGF $\beta$ tumor promotion may occur predominantly in situations where signaling receptor expression is deficient [15].

Loss of TGF $\beta$ tumor suppressor signaling is important in a tumor cell's ability to evade apoptotic signaling in the tumor microenvironment. Previously, our laboratory identified the linkage of TGF $\beta$ tumor suppressor activity to the repression of pro-survival PI3K/AKT signaling and linked the PI3K/AKT pathway to survivin expression in human colon carcinoma cell lines [16]. AKT has a wide variety of substrates involved in many cellular responses including proliferation, apoptosis and growth. Over-expression and/or constitutive signaling of PI3K/ AKT pathway components have frequently been implicated in the regulation of cell survival and their association with tumor progression [17].

Survivin, also known as Birc5, is a $16.5 \mathrm{kDa}$ protein that is the smallest member of the inhibitors of apoptosis (IAP) family. Survivin is expressed in the nucleus, the cytosol and the mitochondria. Survivin is expressed in proliferating cells such as embryonic and fetal cells and is undetectable in differentiated normal tissue; however, survivin is highly expressed in numerous solid tumor types including colon, breast, lung and liver, and its expression is associated with aberrant cell survival and tumor progression [18-20]. Overexpression of survivin has been associated with inhibition of cell death initiated by extrinsic or intrinsic apoptotic pathways [21]. Survivin expression is associated with poor clinical prognosis in many tumor types including colon, lung and breast [22-25]. Survivin protects X-linked inhibitor of apoptosis (XIAP) from proteasomal degradation and antagonizes apoptosome-mediated cell death through the ability of XIAP to inhibit caspase activation [26]. It has been shown that upon cellular stress, mitochondrial survivin is released into the cytosol where it interacts and stabilizes XIAP and provides protection from cell death [27]. The Bir2 domain of XIAP has been linked with inhibition of caspase 3 and caspase 7; and the Bir3 domain with caspase 9 inhibition [28]. AKT/PKBmediated phosphorylation of XIAP within the Bir1 domain is implicated in reducing auto-ubiquitination and enhanced protein stabilization [29].

Many studies indicate that aberrant TGF $\alpha / E G F R$ signaling is involved in tumor progression [30-34]. The FET colon cancer cell line which normally does not form subcutaneous xenografts in athymic mice [35] becomes highly tumorigenic after TGF $\alpha$ (transforming growth factor- $\alpha$ ) transfection to generate constitutive EGFR (epidermal growth factor receptor) activation [36]. FET cells have robust autocrine TGF $\beta$ signaling that inhibits cell proliferation and contributes to apoptosis in response to stress [16]. We show here that FET $\alpha$ cells exhibit robust invasion at the primary site after orthotopic implantation. The ability to invade at the primary site is the key attribute in the assignment of cancer diagnosis [37]. Importantly, however, despite invasive capabilities, the FET $\alpha$ cells rarely metastasize when implanted at the orthotopic site of the colon in athymic mice. Ye et al. [38] demonstrated that repression of TGF $\beta$ activity by transfection of dominant negative (DN) TGF $\beta$ RII was sufficient to lead to vigorous tumor growth by FET cells in subcutaneous implants; however, as with FET $\alpha$ cell induced tumors FETDNRII orthotopic implants without ectopic TGF $\alpha$ expression resulted in invasive primary cancers that rarely metastasized. Since the TGF $\beta$ receptor/SMAD signaling in FET $\alpha$ cells remained intact, we hypothesized that suppression of this pathway would be sufficient to generate a metastatic phenotype in association with increased resistance to apoptosis in response to stress from orthotopic transplants. Two mechanisms contributing to increased survival associated with loss of TGF $\beta$ tumor suppressor activity are constitutive AKT activation and survivin/XIAP expression. These results show that in addition to suppression of tumor initiation, 
TGF $\beta$ signaling provides a direct mechanism of metastatic suppression in established carcinomas. To substantiate our findings that TGF $\beta$ signaling is a metastatic suppressor in established carcinomas, we utilized a human colon carcinoma cell line (designated CBS) that is metastatic after orthotopic implantation and demonstrates loss of TGF $\beta$ signaling due to epigenetic repression of the TGFßRII. Ectopic expression of TGF $\beta$ RII in CBS-RII cells resulted in primary carcinoma formation as reflected by invasion, but was accompanied by suppression of the metastatic phenotype in the orthotopic implantation model. Also, reintroduction of Smad-dependent TGF $\beta$ signaling resulted in decreased expression of cytoplasmic survivin and XIAP in CBS-RII cells. Taken together, our results suggest that restoration of TGF $\beta$ signaling in non-responsive metastatic cells can inhibit cell survival and metastases. Moreover, the role of TGF $\beta$ receptor/Smad signaling in curtailing metastatic progression in primary invasive carcinoma suggests that strategies involving inhibition of TGF $\beta$ signaling for cancer treatment may be ill-advised for some subpopulations of cancer patients.

\section{Methods}

\section{Cell lines and reagents}

FET $\alpha$ and FET $\alpha-D N$ colon carcinoma cells were cultured at $37^{\circ} \mathrm{C}$ in a humidified atmosphere of $5 \% \mathrm{CO}_{2}$ in $\mathrm{SM}$ medium [McCoy's 5A serum-free medium (Sigma) with pyruvate, vitamins, amino acids, and antibiotics] supplemented with $10 \mathrm{ng} / \mathrm{mL}$ EGF, $20 \mu \mathrm{g} / \mathrm{mL}$ insulin, and $4 \mu \mathrm{g} / \mathrm{mL}$ transferrin. When the cells were subjected to growth factor deprivation stress (GFDS), they were cultured in SM medium in the absence of growth factor or serum supplements for 24 or $48 \mathrm{~h}$ without medium changes in between. Antibodies for poly (ADP-ribose) polymerase (PARP), AKT, phosphorylated AKT (Ser473), and survivin were obtained from Cell Signaling Technology. Actin and tubulin antibodies were purchased from Sigma. P-Smad2 and XIAP antibodies were from Chemicon and Abcam, respectively. PI3K inhibitor LY294002, and TGF $\beta$ were obtained from Calbiochem. Apoptag plus Peroxidase In Situ Apoptosis Detection kit was from Millipore/Chemicon and both the DAKO Envision System HRP and the monoclonal anti-Human KI-67 antigen (Clone Mib-1) were from DAKO North America. Annexin V-FITC Apoptosis Detection kit (including propidium iodide) was from BD Bioscience Pharmingen while the Cell Death Detection ELISA $^{\text {PLUS }}$ kit was from Roche Diagnostics. Hematoxylin was obtained from Protocol and eosin was from SigmaAldrich.

\section{Ectopic expression of dominant negative TGF $\beta$ RII receptor}

The DNRII expression vector was described previously [38]. The cDNA was subcloned into a MX-IV retroviral vector. The 293GP packaging cells (Clontech, Mountain View, CA) were co-transfected with pVSV-G. The viruses were harvested $48 \mathrm{~h}$ later and used to infect FET $\alpha$ cells. Puromycin $(3.0 \mu \mathrm{g} / \mathrm{mL})$ was used to select infected cells for 8 days and then cells were pooled.

\section{Immunoblot analysis}

Cells were lysed in TNESV lysis buffer [50 mmol/L Tris ( $\mathrm{pH}$ 7.5), $150 \mathrm{mmol} / \mathrm{L} \mathrm{NaCl}, 1 \% \mathrm{NP} 40,50 \mathrm{mmol} / \mathrm{L} \mathrm{NaF}$, $1 \mathrm{mmol} / \mathrm{L} \quad \mathrm{Na}_{3} \mathrm{VO}_{4}, 25 \mu \mathrm{g} / \mathrm{mL}$ h-glycerophosphate, $1 \mathrm{mmol} / \mathrm{L}$ phenylmethylsulfonyl fluoride, one protease inhibitor cocktail tablet (Roche, Indianapolis, IN) per $10 \mathrm{~mL}$ ] for 30 minutes on ice. The supernatants were then collected by centrifugation at $21,000 \times \mathrm{g}$ for $15 \mathrm{~min}-$ utes at $4^{\circ} \mathrm{C}$. Protein was determined by the Pierce BSA method. Proteins samples were dissolved in $1 \times$ sample buffer (50 mM Tris, pH6.8, 1\% SDS, 10\% glycerol, 0.03\% bromophenol blue and $1 \% \beta$-mercaptoethanol). Protein (10-50 $\mu \mathrm{g}$ ) was fractionated on a $10 \%$ acrylamide denaturing gel and transferred onto a nitrocellulose membrane (Life Science, Amersham) by electroblotting. The membrane was blocked with $5 \%$ nonfat dry milk in TBST [50 mmol/L Tris (pH 7.5), $150 \mathrm{mmol} / \mathrm{L} \mathrm{NaCl}$, $0.05 \%$ Tween 20] for $1 \mathrm{~h}$ at room temperature or overnight at $4^{\circ} \mathrm{C}$ and washed in TBST. The membrane was then incubated with primary antibodies at 1:1000 dilutions for $1 \mathrm{~h}$ at room temperature or overnight at $4^{\circ} \mathrm{C}$. After washing with TBST for $30 \mathrm{~min}$, the membranes were then incubated with peroxidase-conjugated goat anti-mouse or anti-rabbit IgG (Jackson ImmunoResearch Laboratories, Inc) at a 1:1,000 dilution for $1 \mathrm{~h}$ at room temperature. After further washing in TBST for $30 \mathrm{~min}$, the proteins were detected by the enhanced chemiluminescence (ECL) system (Amersham) or SuperSignal West Pico Chemiluminescent Substrate (Thermo Scientific).

\section{Immunoprecipitation}

Cells were lysed in TNESV lysis buffer for 30 minutes on ice. The supernatants were then collected by centrifugation at $21,000 \times \mathrm{g}$ for 15 minutes at $4^{\circ} \mathrm{C}$. Protein was determined by the Pierce BSA method. Protein (300 ug) was pre-cleared with $10 \mathrm{ul}$ of protein A/G beads and lysis buffer for 30 minutes at $4^{\circ} \mathrm{C}$. Samples were centrifuged at $21,000 \times \mathrm{g}$ at $4^{\circ} \mathrm{C}$ for 10 minutes followed by collection of the supernatant. The supernatant was incubated while rotating with antibody (according to the manufacturer's specifications) at $4{ }^{\circ} \mathrm{C}$ for 60 minutes, followed by addition of 25 ul protein A/G beads and tumbled overnight. Samples were centrifuged at $21,000 \times \mathrm{g}$ for 1 minute at $4^{\circ} \mathrm{C}$. The supernatant was collected to probe for actin as an experimental control, while the pellet was washed 3 times for 5 minutes in lysis buffer at $21,000 \times \mathrm{g}$ at $4^{\circ} \mathrm{C}$, each time the supernatant was decanted. The pellets were dissolved in 
20 ul 1x sample buffer (50 mM Tris, pH6.8, 1\% SDS, 10\% glycerol, $0.03 \%$ bromophenol blue and $1 \% \beta$-mercaptoethanol) and boiled for 5 minutes at $95^{\circ} \mathrm{C}$, then spun and loaded on SDS-PAGE gel.

\section{DNA fragmentation (cell death ELISA)}

Apoptosis was quantified by a DNA fragmentation ELISA. Briefly, cells were seeded in plates in serum-free medium and allowed to attach for 24 hours. Medium was changed on alternate days until $80 \%$ confluence was attained. Next, the medium was changed to supplemental McCoys for 24 or $48 \mathrm{~h}$ of growth factor deprivation stress (GFDS). DNA fragmentation was detected by the Cell Death Detection ELISA Plus kit (Roche, Indianapolis, IN) according to the manufacturer's instructions. DNA fragmentation was normalized by MTT assays derived at identical treatment conditions.

MTT (3-(4, 5-dimethylthiazol-2-yl)-2, 5diphenyltetrazolium bromide)

Cells were grown to $80 \%$ confluence then MTT was added to the medium followed by incubation at $37^{\circ} \mathrm{C}$ for $2 \mathrm{~h}$. The medium was aspirated to visualize stained cells. DMSO was added and the plate was covered with foil followed by shaking for $15 \mathrm{~min}$. Duplicates volumes $(150 \mu \mathrm{L})$ were added to a 96-well plate and the absorbance was observed at $570 \mathrm{~nm}$.

\section{$\left[{ }^{3} \mathrm{H}\right]$ Thymidine incorporation}

$\left[{ }^{3} \mathrm{H}\right]$ Thymidine incorporation was used to determine cell cycle inhibition of FET $\alpha$ and FET $\alpha \mathrm{DN}$ cells after TGF- $\beta$ treatment. The cells were seeded in six-well tissue culture plates and grown to $60 \%$ confluence. At $48 \mathrm{~h}$ after TGF $\beta$ treatment, the cells were labeled with $\left[{ }^{3} \mathrm{H}\right]$ thymidine $(7 \mu \mathrm{Ci} ; 46 \mathrm{Ci} / \mathrm{mmol}$; Amersham Corp.) for $1 \mathrm{~h}$. DNA was then precipitated with $10 \%$ trichloroacetic acid and solubilized in $0.2 \mathrm{~mol} / \mathrm{L} \mathrm{NaOH}$. The amount of $\left[{ }^{3} \mathrm{H}\right]$ thymidine incorporated was analyzed by liquid scintillation counting in a Beckman LS7500 scintillation counter.

\section{Immunohistochemistry (IHC)}

Primary tumors established from the FET $\alpha$ and FET $\alpha$ DN cells were harvested and placed in $10 \%$ neutral buffered formalin fixative for 12 to $24 \mathrm{hrs}$ and then embedded in paraffin. Deparaffinized tissue specimens were subjected to immunohistochemical staining for the detection of pAKT-S473, survivin and XIAP using an indirect detection method [39]. The catalyzed signal amplification system was used for the phosphospecific antibodies (Dako Corporation, Carpinteria, CA). The antibody staining was accompanied by a negative control in which slides were incubated with a matching blocking peptide (Dako Corporation) to the primary antibody.
Specimens were processed on the same day to eliminate any variability in conditions. Slides were digitally photographed using the same settings.

\section{Terminal deoxynucleotidyl transferase-mediated dUTP nick end labeling (TUNEL) assay}

Slides were cut from paraffin embedded blocks and stained according to the Apotag (Oncor, Gaithersburg, $\mathrm{MD}$ ) terminal nucleotidyl transferase-mediated nick end labeling (TUNEL) assay kit. The apoptotic rate was quantitatively determined by counting the number of positively stained apoptotic bodies per $75 \mu^{2}$ field at 200x magnification. Twelve and fifteen histological slides for the FET $\alpha$ and FET $\alpha$-DN tumors, respectively, were analyzed. Three histologically similar fields viewed at 200X were randomly selected from each slide for analysis. This procedure was performed by two blinded observers. The ratio of the average number of apoptotic cells to the total number of cells counted was used to represent apoptotic rates.

\section{$\mathrm{KI}-67$ staining}

Slides cut from paraffin embedded blocks were also used for H\&E stains and for immunohistochemical characterizations. Serial sections were cut to complement the $\mathrm{H} \& \mathrm{E}$ sections and were stained with an $\mathrm{IgG}_{1}$ rabbit polyclonal antibody for Ki-67 (Dako Corporation). Ki-67 is a non-histone nuclear antigen present in late $G_{1}, G_{2}$, and $S$ phase of the cell cycle but not $G_{0}$. The optimal dilution of 1:100 was used. Three- to $4-\mu \mathrm{m}$ sections were cut, deparaffinized in xylene, and rehydrated in descending grades of ethanol. Endogenous peroxidase activity was blocked with $3 \%$ hydrogen peroxide in water. Immunostaining was done using a variation of the avidin-biotin-peroxidase method. Slides were counterstained with methyl green. The proliferation rate was determined quantitatively by utilization of NIH Image J (public domain software). Image settings were as follows: threshold range 10-192; pixel size 20-5000. Twelve slides from FET $\alpha$ and FET $\alpha$-DN were analyzed. Three histologically similar fields viewed at 200X were randomly selected for analysis. The mean proliferation was determined for each group.

\section{Subcellular fractionation}

Cells were washed with phosphate buffered saline (PBS) then lysed using $500 \mu \mathrm{l}$ of fractionation buffer $(250 \mathrm{mM}$ Sucrose, $20 \mathrm{mM}$ HEPES pH7.4, $0 \mathrm{mM} \mathrm{KCl}, 1.5 \mathrm{mM}$ $\mathrm{MgCl}_{2}, 1 \mathrm{mM}$ EDTA, mM EGTA). Cells were scraped immediately and placed in a $1.5 \mathrm{ml}$ eppendorf tube on ice. Collected cells were then passed through a $25 \mathrm{G}$ needle 10 times, and incubated on ice for $20 \mathrm{~min}$. Cells were centrifuged at $720 \times \mathrm{g}(360 \mathrm{rpm})$ for $5 \mathrm{~min}$ to isolate the nuclear pellet from the supernatant containing 
the cytoplasm. The nuclear pellet was washed with fractionation buffer and passed through a $25 \mathrm{G}$ needle 10 times followed by centrifugation at $720 \times \mathrm{g}(360 \mathrm{rpm})$ for $10 \mathrm{~min}$ again. The supernatant containing the cytoplasm was centrifuged at $14,000 \times \mathrm{g}(8000 \mathrm{rpm})$ for $10 \mathrm{~min}$ to yield the cytosolic fraction (supernatant) and the mitochondrial fraction (the pellet). The mitochondrial pellet was washed with fractionation buffer and passed through a $25 \mathrm{G}$ needle 10 times followed by centrifugation at $14,000 \times \mathrm{g}(8000 \mathrm{rpm})$ for $10 \mathrm{~min}$ again then re-suspended in the appropriate volume of fractionation buffer.

\section{Orthotopic implantation}

Orthotopic implantation was performed as previously described [40]. Briefly, green fluorescent protein (GFP)labeled FET $\alpha$ and FET $\alpha$-DN cells $\left(5 \times 10^{6}\right)$ were subcutaneously injected onto the dorsal surfaces of separate $\mathrm{BALB} / \mathrm{c}$ nude male mice and allowed to grow to $300 \mathrm{~mm}^{3}$. Once xenografts were established, they were excised and minced into $1 \mathrm{~mm}^{3}$ pieces. Two of these pieces were then orthotopically implanted into the colon of other BALB/c nude mice. Forty four animals were implanted with FET $\alpha$ xenografts and 30 animals with FET $\alpha$-DN xenografts. For operative procedures, animals were anesthetized with isoflurane inhalation. A $1-\mathrm{cm}$ laparotomy was performed and the cecum and ascending colon were exteriorized. Using 7X magnification and microsurgical techniques, the serosa was disrupted in two locations. Pieces of xenograft $\left(1 \mathrm{~mm}^{3}\right)$ were subserosally implanted using an 8-0 nylon suture at the disrupted serosal locations. The bowel was then returned to the peritoneal cavity and the abdomen was closed with 5-0 vicryl suture. Fluorescence imaging was performed weekly on the animals to follow tumor growth (LightTools). Animals were euthanized at 7-9 weeks after implantation. Organs were explanted, imaged, and immediately placed in buffered $10 \%$ formalin. Tissues were then processed and embedded in paraffin. Histological slides were cut for H\&E staining. Metastases were determined by histological evaluation of each liver lobe and both lungs as previously described in detail $[41,42]$. All animal work was done in accordance with the Institutional Animal Care and Use Committees (IACUC) regulations. Protocol number was $920 \mathrm{M}$.

\section{Imaging}

Starting at one week post-implantation, animals were anesthetized with a 1:1 mixture of ketamine $(10 \mathrm{mg} / \mathrm{ml})$ and xylazine $(1 \mathrm{mg} / \mathrm{ml})$ by intraperitoneal injection $(0.01 \mathrm{ml} / \mathrm{mg})$ and weekly GFP fluorescence imaging was performed for up to seven weeks. Specifically, GFP fluorescence imaging was performed using a light box illuminated by fiber optic lighting at $470 \mathrm{~nm}$ (Illumatool BLS,
Lightools Research, Encinitas, CA) using a Retiga EXi color CCD camera (QImaging, Burnaby BC, Canada). High-resolution images consisting of 1,360 X 1036 pixels were captured directly using a MS-Windows based PC. Images were visually optimized for contrast and brightness using commercial software (Adobe Photoshop, CS2 Adobe, San Jose, CA). Excitation of GFP in the light box facilitated identification of primary and metastatic disease by direct near-real time visualization of fluorescence in live animals.

\section{Results}

\section{TGF $\beta$ suppresses metastasis in vivo}

We have reported that the FET cell line which was isolated from a human colon cancer is immortalized and grows with anchorage independence, but does not form tumors in athymic mice after subcutaneous implantation [32]. Stable transfection with a construct coding for active (processed) TGF $\alpha$ under TET off control resulted in progressive growth at the subcutaneous site in the absence of TET. With the addition of TET the FET $\alpha$ tumors showed regression in association with high apoptotic rates as reflected by TUNEL [33]. FET $\alpha$ cells as well as the parental FET cell line have a high sensitivity to TGF $\beta$ in contrast to most cancer derived cell lines. We hypothesized that TGF $\beta$ signaling suppresses metastasis of FET $\alpha$ cells. To test this hypothesis, we stably cotransfected FET $\alpha$ cells with a dominant negative RII receptor construct and denoted these cells as FET $\alpha-\mathrm{DN}$. Abrogation of TGF $\beta$ signaling was confirmed by treating FET $\alpha$ and FET $\alpha-D N$ cells with varying concentrations of TGF $\beta[0,5,10 \mathrm{ng} / \mathrm{mL}]$ for $2 \mathrm{~h}$ followed by immunoblot analysis. Phospho-Smad2 was used as an indicator of functional TGF $\beta$ signaling. FET $\alpha$ cells showed a concentration-dependent induction of pSmad2 while FET $\alpha-D N$ cells showed no pSmad2 expression. This result confirmed loss of TGF $\beta$ receptor mediated Smad signaling in FET $\alpha$-DN (see Additional file 1).

Comparison of FET $\alpha$ and FET $\alpha$-DN cells by orthotopic implantation was used to assess the effect of loss of TGF $\beta$ receptor/Smad signaling on malignant progression beyond the first step of the metastatic process (invasion of the primary tumor) as reflected by metastatic colonization of distant organs from the primary tumor site. Forty four animals were implanted with FET $\alpha$ cells and 30 animals with FET $\alpha-D N$ cells. Metastatic spread was analyzed in liver and/or lungs of transplanted mice as described in the methods. The presence or absence of metastatic disease was determined by microscopic histological analysis of lungs and liver from mice bearing orthotopic implants as previously described [42]. We observed $100 \%$ primary tumor growth and invasion at the primary site of implantation for all animals, however only $2 / 44$ animals showed metastatic colony formation 
in the lungs or liver from orthotopic implantation of FET $\alpha$ cells (Table 1). Figure 1A shows images of FET $\alpha$ implants with GFP fluorescence of isolated primary tumor tissue and lungs with no visible GFP fluorescence. Table 2 summarizes the results of orthotopic implantation with subcutaneous xenografts formed by injection of FET $\alpha-D N$ cells. As with FET $\alpha$ orthotopic implants we observed $100 \%$ primary tumor growth and invasion at the primary site of implantation for all animals: in addition, visible GFP fluorescence from metastatic cells was evident in the lungs. The results show that $23 / 30$ animals from FET $\alpha-D N$ bearing animals had metastatic colony formation in the lungs. Figure $1 \mathrm{~B}$ shows images of FET $\alpha-D N$ implants with GFP fluorescence by primary tumor tissue and lungs with visible deposits of GFP fluorescent colonies. Metastatic colonization was also evaluated histologically by hematoxylin and eosin (H\&E) staining as described in the methods. Figure $1 \mathrm{C}$ shows $\mathrm{H} \& \mathrm{E}$ staining of FET $\alpha$ and FET $\alpha-\mathrm{DN}$ primary tumors; as well as metastatic colonies in the lungs of FET $\alpha-D N$ orthotopically implanted animals. These results indicate that while FET $\alpha$ and FET $\alpha-D N$ cells are both $100 \%$ invasive at the primary implanted site, however, there was a robust increase observed in metastatic potential after removal of TGF $\beta$ signaling by DNRII. FET $\alpha$ bearing animals had a $5 \%$ metastatic rate compared to a $77 \%$ metastatic rate observed in FET $\alpha-\mathrm{DN}$ bearing animals for equally sized primary tumors using previously described histological assessment methodology [42].

The increased metastatic capability of FET $\alpha-D N$ implants suggests that these cells acquired enhanced survival capabilities enabling them to escape from the primary tumor site to form colonies at a distal organ site as a result of loss of TGF $\beta$ inhibitory signaling. Proliferative potential and survival signaling were assessed in situ by KI-67 [43] and TUNEL assays [44] as previously described [42]. Immunohistochemical staining of KI-67 showed that both FET $\alpha$ and FET $\alpha-D N$ tumors had positive staining for KI-67 antigen. KI-67 staining indicated no differences in the proliferation rates between FET $\alpha$ and FET $\alpha-\mathrm{DN}$ implanted animals (Figure 2A and 2B). However, TUNEL staining was higher in tumors from FET $\alpha$ implanted animals thus, reflecting a larger number of cells undergoing apoptosis in FET $\alpha$ tumors as compared to FET $\alpha$-DN tumors (Figure 2C). The apoptotic rate of FET $\alpha$ implants was 2.5-fold that of FET $\alpha$-DN implants (Figure 2D). Taken together these results indicate that the level of TGF $\beta$ receptor/Smad signaling in FET $\alpha$ cells is not capable of suppressing tumor initiation

Table 1 FETa implant develop primary invasion but no metastasis

\begin{tabular}{|c|c|c|}
\hline$\frac{\text { Implant }}{\text { FETa }}$ & $\frac{\text { Primary Invasion }}{(100 \%)} 44 / 44$ & $\frac{\text { Metastasis }}{(5 \%)} 2 / 44$ \\
\hline
\end{tabular}

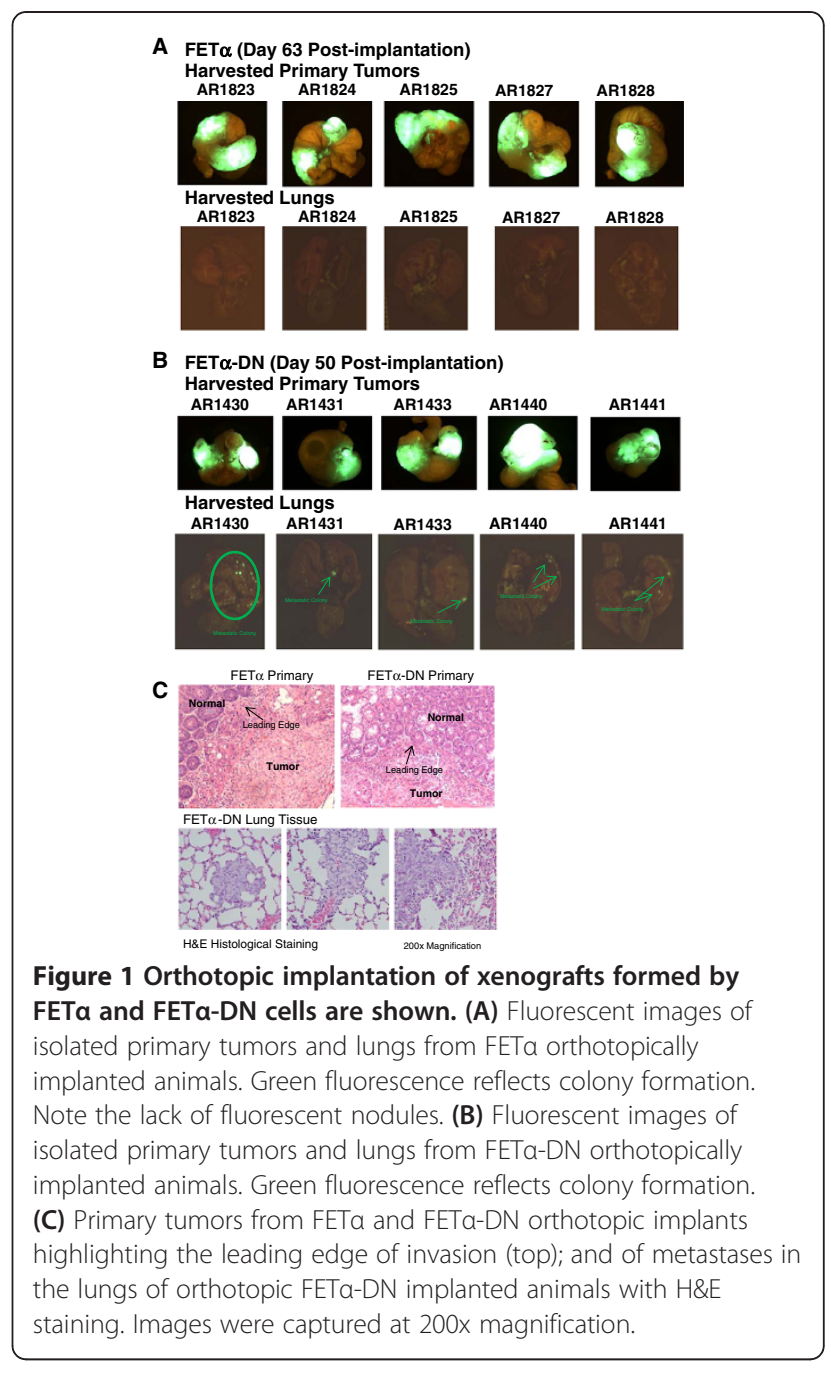

and invasion, but does suppress the progression of a primary invasive carcinoma to a robust metastatic capability. Thus, shifting the tumor suppressor/oncogenic balance toward oncogenesis by constitutive EGFR activation allows for malignancy, but not a robust metastatic phenotype due to continued metastasis suppressor signaling by TGF $\beta$.

\section{Abrogation of TGF $\beta$ tumor suppressor signaling in vitro results in enhanced survival during GFDS}

The ability of FET $\alpha$ cells to carry out invasion at the primary site, but not carry out subsequent aspects of the metastatic cascade due to TGF $\beta$ signaling suggests that this tumor suppressor activity is strong enough to shift the balance of tumor suppressor/oncogenesis signaling toward cell death when these cells encounter the stresses associated with various steps that must be traversed in

Table 2 Loss of TGF $\beta$ tumor suppressor activity results in robust metastasis

\begin{tabular}{lll}
\hline Implant & Primary Invasion 30/30 & Metastasis 23/30 \\
& $\frac{(100 \%)}{(77 \%)}$ \\
\hline
\end{tabular}




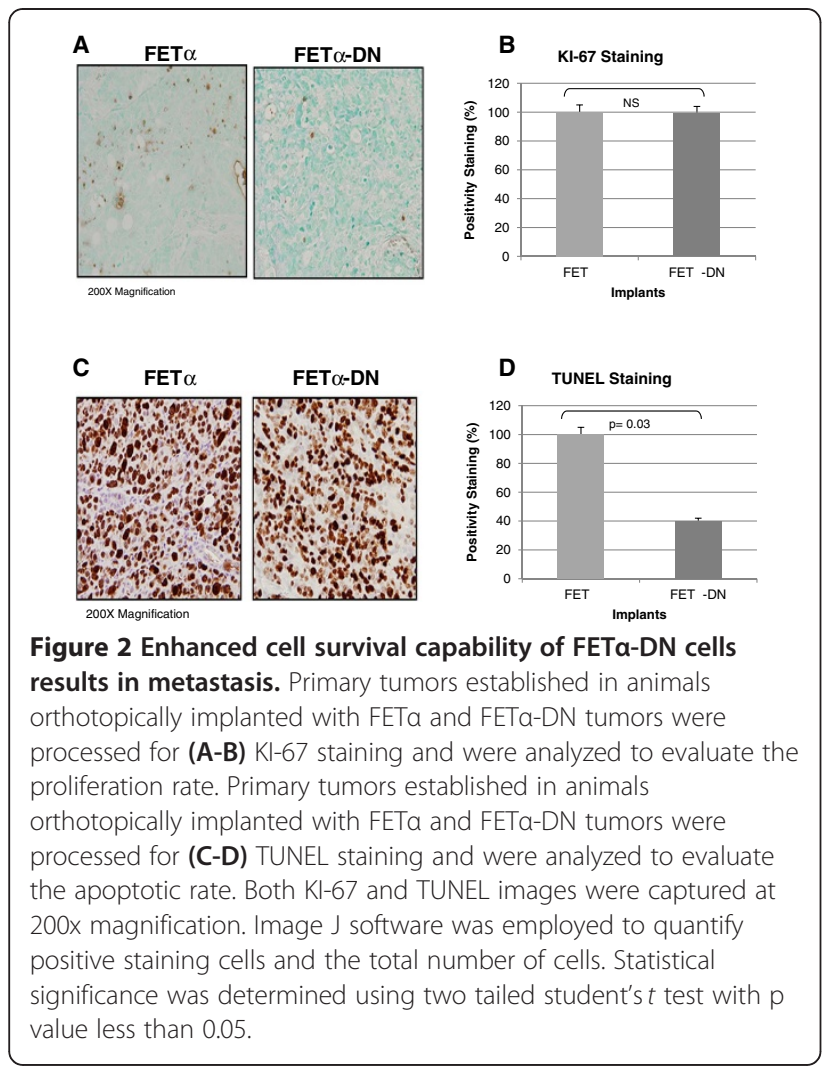

the metastatic process such as circulation in the blood and/or colonization in the foreign microenvironment of distant organs (reviewed by Mehlen and Puisieux [4]). The loss of TGF $\beta$ associated tumor suppressor activity would be expected to shift this balance towards a higher capacity for cell survival in the FET $\alpha$-DN cells. To test the hypothesis that loss of TGF $\beta$ tumor suppressor signaling resulted in a higher capacity for cell survival, we utilized growth factor deprivation as a cell survival stress model to compare FET $\alpha$ and FET $\alpha-\mathrm{DN}$ cells as previously described for FET cells [16]. Cells were deprived of growth factors for $48 \mathrm{~h}$ followed by determination of apoptosis. Assessment for apoptotic behavior was performed by immunoblot analysis probing for poly-(ADPribose) polymerase (PARP) expression and cleavage. The appearance of cleaved products of PARP $(88 \mathrm{kDa})$ has been widely used as an indicator of apoptosis [45]. Immunoblot analysis was used to probe for PARP following $48 \mathrm{hrs}$ GFDS. Figure 3A illustrates that PARP cleavage is robust in FET $\alpha$ cells deprived of growth factors for $48 \mathrm{~h}$ while PARP cleavage in FET $\alpha$-DN cells is low. Additional confirmation of an enhanced survival phenotype in FET $\alpha$-DN cells was obtained by DNA fragmentation analysis after 48 hrs GFDS. Figure 3B indicates that FET $\alpha$ cells had a time dependent increase in DNA fragmentation during GFDS (up to 7-fold at $48 \mathrm{~h}$ ) as compared to FET $\alpha$-DN cells. Taken together, these

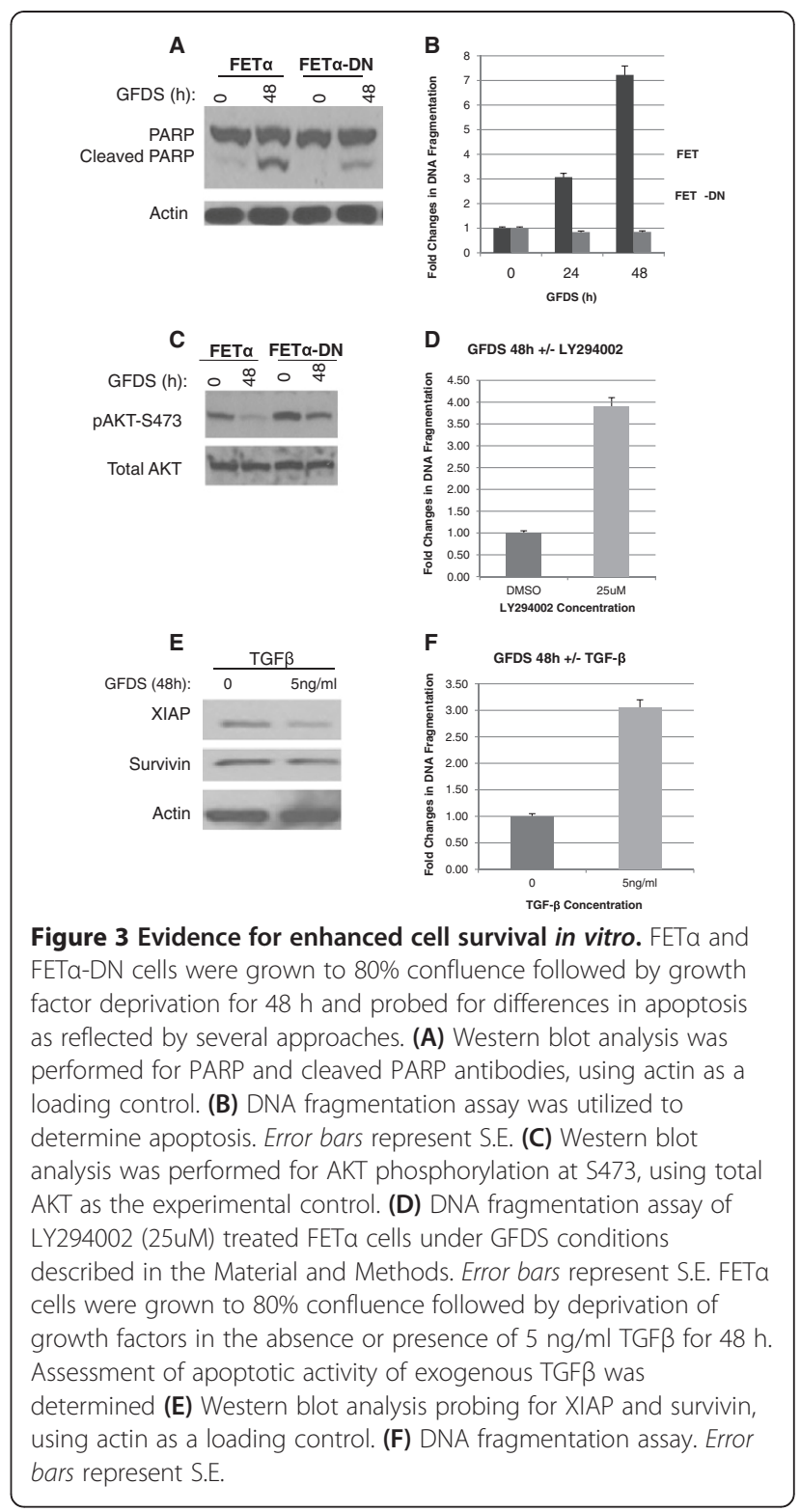

results indicate that endogenous TGF $\beta$ signaling is responsible for a high level of apoptotic signaling in FET $\alpha$ cells as abrogation of TGF $\beta$ inhibitory signaling in the FET $\alpha$-DN cells rendered the cells more resistant to apoptosis.

\section{Increased AKT activation and survivin/XIAP expression through repression of TGF $\beta$ signaling contributes to cell survival}

Based on our previous observation that endogenous TGF $\beta$ signaling repressed PI3K/AKT signaling in tissue culture and that this repression was critical to induction of apoptosis in stressed FET cells [16], we determined whether PI3K/AKT activation by repression of TGF $\beta$ signaling contributed to the enhanced cell survival that resulted from loss of TGF $\beta$ inhibitory signaling in FET $\alpha$ - 
DN cells using pAKT modulation as an indicator of PI3K/AKT signaling. Cells were grown to $80 \%$ confluence and deprived of growth factors for $48 \mathrm{~h}$ then subjected to immunoblot analysis for AKT phosphorylation. The results showed that phosphorylation of AKT was decreased in FET $\alpha$ cells relative to FET $\alpha$-DN cells under both GFDS stress and normal growth conditions (Figure $3 \mathrm{C}$ ). To confirm that PI3K/AKT signaling was linked to cell survival in FET $\alpha-\mathrm{DN}$ cells we treated cells with LY294002, a potent inhibitor of PI3K. The effect of LY294002 inhibition on cell survival was determined by growing cells to $80 \%$ confluence followed by growth factor deprivation for $48 \mathrm{~h}$ in the presence of DMSO or 25 uM LY294002. Confirmation of inhibition of apoptosis was assessed by DNA fragmentation analysis. Results demonstrated that LY294002 treated FET $\alpha-D N$ cells had a 4 fold increase in apoptosis compared to DMSO treated cells (Figure 3D).

Survivin has been implicated in aberrant cell survival exhibited by tumorigenic cells [24]. AKT mediated phosphorylation of XIAP within the Bir1 domain has been shown to reduce ubiquitination of this protein and thus enhance its stabilization [29]. There is evidence indicating that XIAP is stabilized through its interaction with survivin [27]. Survivin protects XIAP from proteasomal degradation and antagonizes apoptosome-mediated cell death through the ability of XIAP to inhibit caspase activation [26]. Consequently, we hypothesized inhibition of TGF $\beta$ signaling would also enhance expression of both survivin and XIAP. Cells were grown to $80 \%$ confluence then treated with $5 \mathrm{ng} / \mathrm{mL}$ TGF $\beta$ in combination with GFDS for $48 \mathrm{~h}$ followed by immunoblot analysis for survivin, XIAP and actin. As shown in Figure 3E, exogenous TGF $\beta$ inhibited survivin and XIAP expression in stressed FET $\alpha$ cells. To assess the effect of TGF $\beta$ treatment on cell survival, cells were treated in the presence or absence of $5 \mathrm{ng} / \mathrm{mL}$ TGF $\beta$ in combination with GFDS for $48 \mathrm{~h}$ followed by DNA fragmentation assays which showed a 3-fold increase in DNA fragmentation of FET $\alpha$ cells treated with TGF $\beta$ (Figure 3F). These results indicate that TGF $\beta$ mediated inhibition of survivin and XIAP expression is associated with FET $\alpha$ cell sensitivity to apoptosis.

Localization of survivin plays a major role in its function. Survivin can be nuclear, mitochondrial, cytoplasmic or associated with the mitotic apparatus [46]. It has been reported that tumor cells have high levels of survivin in the mitochondria that are released into the cytosol upon stress stimulation to provide a cytoprotective effect [26]. Cytoplasmic survivin binds XIAP and enhances XIAP stability by protecting it from proteasomal degradation and antagonizes apoptosomemediated cell death through the ability of XIAP to inhibit caspase activation in vivo [26]. Therefore we hypothesized that abrogation of TGF $\beta$ signaling resulted in enhanced expression of survivin and XIAP in the cytoplasm. To test this hypothesis we performed subcellular fractionation to interrogate survivin and XIAP localization in FET $\alpha$ versus FET $\alpha-D N$ cells in vitro. The rationale for separation of the cytosolic and mitochondrial fractions was to assess whether there were differences in the cytoplasmic pools of survivin between the cell lines that correlates with the enhanced cell survival signaling observed in FET $\alpha$-DN cells. Porin was used as a mitochondrial specific control, while Hsp70 was used as a cytosolic compartment marker. Figure $4 \mathrm{~A}$ shows that FET $\alpha-\mathrm{DN}$ cells have more cytosolic and mitochondrial survivin and XIAP, while no difference was observed in nuclear survivin (data not shown). Immunoprecipitation (IP)/western blot analysis was performed to confirm that the stabilizing complex formation by these two proteins was more prominent in FET $\alpha-D N$ cells. Figure 4B shows FET $\alpha$ and FET $\alpha-D N$ lysates subjected to IP for XIAP followed by immunoblot analysis of survivin, while the supernatant was probed for actin as an experimental control. Our results showed that FET $\alpha-\mathrm{DN}$ cells have greater complex formation between XIAP and survivin proteins under stress conditions than FET $\alpha$ cells.

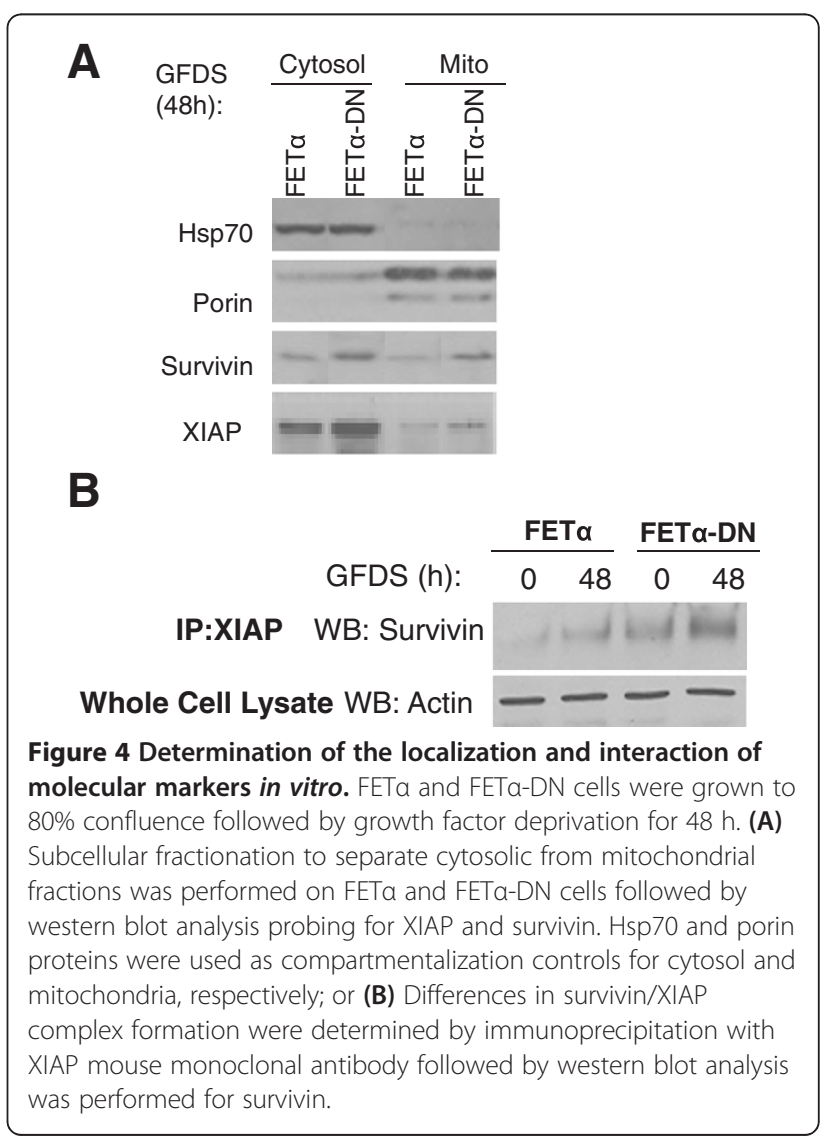


To ascertain whether enhanced in vitro molecular marker expression was also reflected in vivo, immunohistochemical staining (IHC) using specific antibodies for pAKT and XIAP was employed to stain tissue sections of orthotopic implants. IHC staining of FET $\alpha$ and FET $\alpha-D N$ orthotopic implants was performed with a phosphospecific AKT S473 antibody. A blocking peptide that corresponds to the same epitope as the antibody was used as a negative control. Not surprisingly, AKT activation was visible in both FET $\alpha$ and FET $\alpha-D N$ histological slides processed simultaneously. However, the intensity of staining was more pronounced in the FET $\alpha-D N$ implants (Figure 5A). To determine whether differences in XIAP expression were associated with cell survival, IHC staining was performed on FET $\alpha$ and FET $\alpha-D N$ implants with a XIAP specific antibody and a specific blocking peptide control (Figure 5B). Our results showed that FET $\alpha-D N$ implants had stronger staining for XIAP as compared to FET $\alpha$ implants. Collectively, these results indicate that TGF $\beta$ signaling leads to repression of activated $\mathrm{AKT}$ and XIAP expression, and their subsequent association with cell survival.
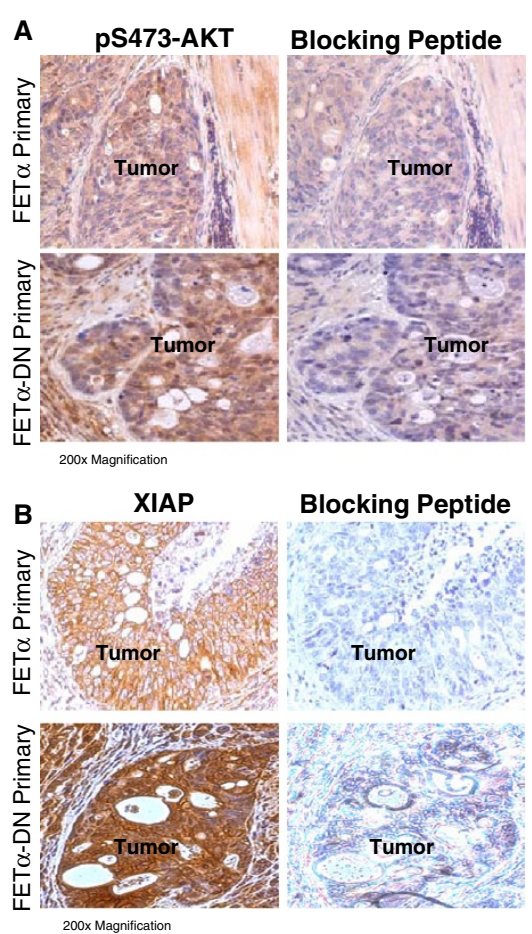

Figure 5 Determination of the status of molecular markers in vivo. (A) Immunohistochemical staining of PAKT-S473 performed on FETa and FETa-DN primary tumors. To confirm antibody specificity, a blocking peptide was used. (B) Immunohistochemical staining of XIAP protein performed on FETa and FETa-DN primary tumors. To confirm antibody specificity, a blocking peptide was used..
Restoration of TGF $\beta$ signaling to native cells with compromised TGF $\beta$ signaling suppressed cell survival and metastasis in vivo

Up to this point demonstration of TGF $\beta$ mediated suppression of metastases was based on genetic blockade of TGF $\beta$ signaling. We extended these results by using the reverse strategy in which metastatic capability in native colon carcinoma cells was reversed through introduction of TGF $\beta$ receptor Smad signaling. CBS is a human colon carcinoma cell line that has attenuated TGF $\beta$ signaling as a result of reduced expression of TGF $\beta$ receptor type II [38]. TGF $\beta$ sensitivity was restored to native CBS cells through stable reintroduction of TGF $\beta$ type II receptor (designated CBS-RII). Subcellular fractionation was performed on CBS and CBS-RII cells to determine whether restoration of TGF $\beta$ receptor signaling resulted in suppression of survivin/XIAP expression. CBS-RII cells exhibited reduced survivin and XIAP expression as compared with CBS cells in vitro (Figure 6). Porin was used as a mitochondrial specific control, while tubulin was used as a cytosolic compartment marker. Reintroduction of Smad-dependent TGF $\beta$ signaling resulted in decreased expression of cytoplasmic survivin and XIAP in CBS-RII cells.

To determine if reintroduction of TGF $\beta$ signaling to the CBS cells would affect their metastatic capability, we performed orthotopic implantation experiments. Figure $7 \mathrm{~A}$ and $7 \mathrm{~B}$ compares GFP fluorescence of the primary cancers and liver isolated from animals orthotopically implanted with CBS-RII or CBS cells, respectively. The

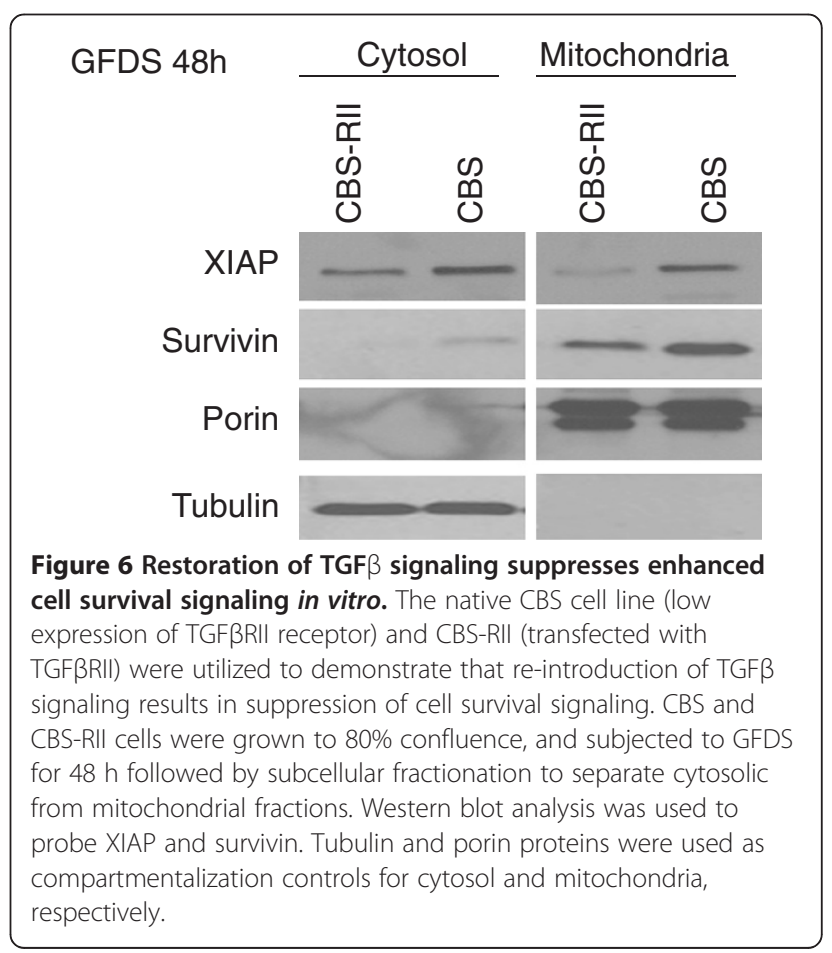


results show that liver from CBS bearing animals had significantly more metastatic colony formation as reflected by green fluorescence, while CBS-RII bearing animals had less. Note that the yellow fluorescence comes from the biliary tree. Table 3 summarizes the results of implantation with xenografts formed by CBS-RII and CBS cells. The lungs and liver of each animal were sequentially sectioned at $1-\mathrm{mm}$ intervals. We observed $100 \%$ invasiveness at the primary tumor site for both cell types. However, distal metastatic colony formation was notably different between CBS and CBS-RII animals, in which 2/20 CBS-RII bearing animals compared to $17 / 26$ CBS bearing animals showed distal metastases. CBS-RII bearing animals had a $10 \%$ metastatic rate compared to a $65 \%$ metastatic rate observed in CBS bearing animals for equally sized primary tumors reflected by a robust reduction of the percentage of animals bearing microscopic metastases using histological assessment methodology previously described [42]. Ectopic expression of TGFBRII in CBS-RII cells did not prevent primary invasive tumor formation but did suppress the metastatic phenotype. Proliferative potential and survival signaling were assessed in situ by KI-67 and TUNEL assays as previously described. Immunohistochemical staining of KI-67 showed that both CBS-RII and CBS tumors had positive staining for KI-67 antigen. KI-67 staining indicated no differences in the proliferation rates between CBS-RII and CBS implanted animals (Figure 7D and $7 F$ ). However, TUNEL staining was higher in tumors from CBS-RII implanted animals thus, reflecting a larger number of cells undergoing apoptosis in CBS-RII tumors as compared to CBS tumors (Figure 7C). The apoptotic rate of CBS-RII implants was 5-fold that of CBS implants (Figure 7E). Taken together these results indicate that restoration of TGF $\beta$ receptor/Smad signaling in CBS-RII cells is not capable of suppressing tumor initiation and invasion, but does suppress the progression of a primary invasive carcinoma to a robust metastatic capability.

\section{Discussion}

TGF $\beta$ primes breast cancer cells for metastasis to the lung through effects on cells in the lung microenvironment [47]. Similarly, TGF $\beta$ interacts with the bone microenvironment to enhance breast cancer metastasis $[47,48]$. Our results show a novel role for TGF $\beta$ signaling in human colon carcinoma, as a direct metastatic suppressor through inhibition of cell survival despite acquisition of malignancy as defined by invasiveness in

Table 3 Restoration of TGF $\beta$ tumor suppressor activity suppresses metastasis

\begin{tabular}{lll}
\hline Implant & $\frac{\text { Primary Invasion 20/20 }}{(100 \%)}$ & $\frac{\text { Metastasis 2/20 }}{(10 \%)}$ \\
& $\frac{\text { Primary Invasion 26/26 }}{(100 \%)}$ & $\frac{\text { Metastasis 17/26 }}{(65 \%)}$ \\
\hline
\end{tabular}
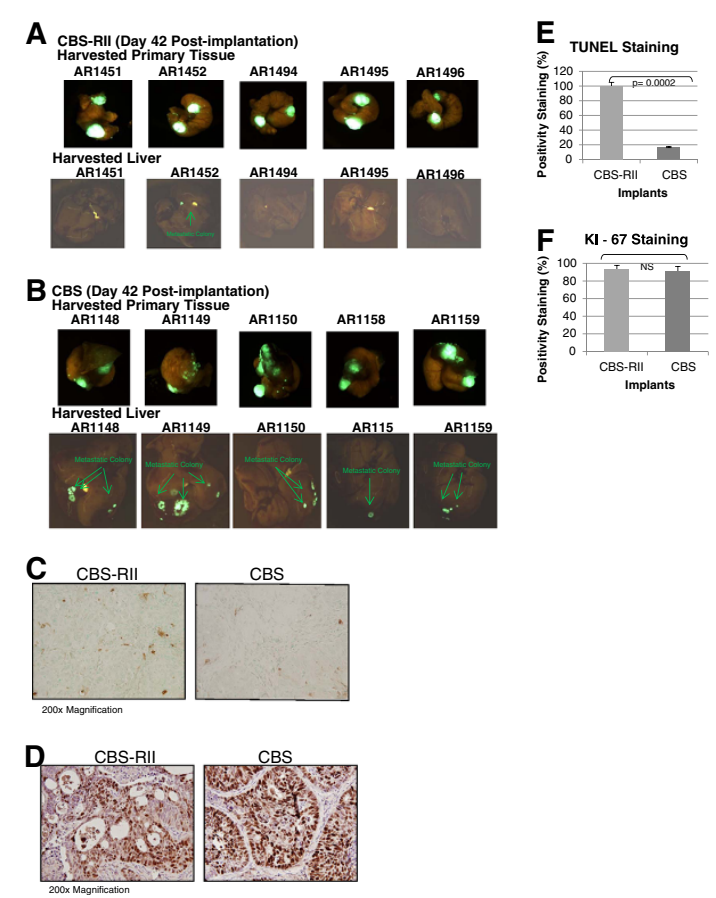

Figure 7 Metastasis is suppressed through reconstitution of TGF $\beta$ signaling. (A) Fluorescent images of primary tumors and the liver from CBS-RIl orthotopically implanted animals. Green

fluorescence reflects metastatic colony formation from the primary tumor. (B) Fluorescent images of primary tumors and the liver from CBS orthotopically implanted animals. Green fluorescence reflects robust metastatic colony formation from the primary tumor. (C-D) Primary tumors established in animals orthotopically implanted with CBS-RII and CBS tumors were processed for KI-67 and TUNEL staining. Both $\mathrm{KI}-67$ and TUNEL images were captured at 200x magnification. (E-F) Primary tumors formed by CBS-RIl and CBS cells were analyzed to evaluate the proliferation and apoptotic rates. Image J software was employed to quantify positive staining cells and total number of cells. Statistical significance was determined using two tailed student's $t$ test with $p$ value less than 0.0002 .

primary cancer cells with low metastatic potential. The mechanism of this pro-apoptotic effect appears to involve inhibition of XIAP mediated cell survival mechanisms. FET $\alpha$ cells have aberrant EGFR activation via TGF $\alpha$ over-expression resulting in formation of invasive primary colon cancer (Figure 1A), but have poor potential for forming distal organ metastasis, due to sensitivity to their intrinsic apoptotic TGF $\beta$ signaling, as shown by high levels of metastatic colonies when TGF $\beta$ signaling was blocked in FET $\alpha-D N$ cells (Figure 1B). We have shown that primary tumor formation is linked to enhanced cell survival mechanisms exhibited by these cells [33]. The importance of cell survival is further emphasized by the observation that abrogation of TGF $\beta$ signaling in the FET $\alpha$-DN cells does not affect invasion at the primary site but facilitates secondary site colonization. 
The metastatic process is complex and has multiple mechanisms that must be acquired by tumor cells before they obtain a robust metastatic capability. Two important rate limiting steps to metastasis are invasion and distal colony formation. There are few in vivo model systems that enable the study of both invasion and distal colony formation. We have utilized an orthotopic implantation model of colon cancer to allow observation of these events. The orthotopic implantation model allows for assessment of the progression of colon cancer evident by invasion at the primary tumor site and distal colonization to the liver and lungs. These sites of metastasis recapitulate the natural progression of human disease. Our results show that both FET $\alpha$ and FET $\alpha-D N$ cells were able to invade the bowel wall and the normal colon crypts to form a carcinoma. However, the orthotopic implants showed that the FET $\alpha-\mathrm{DN}$ cells with abrogated TGF $\beta$ signaling were able to effectively generate colonies despite the stress of growth in the foreign microenvironment of distal organs, emphasizing the role of TGF $\beta$ as a metastasis suppressor as well as a tumor suppressor.

The reconstitution of TGF $\beta$ receptor signaling in CBSRII cells resulted in decreased metastases indicating the potential for treatment of metastasis through enhanced TGF $\beta$ receptor mediated signaling. The balance between oncogenes and tumor suppressor activities is a necessity for normal functioning cells and tissues; however, when the balance shifts towards oncogenicity it results in tumorigenesis and malignant progression. CBS cells have been shown to be similar to the FET $\alpha$ engineered cells in that they have constitutive EGFR activation in addition to the attenuation of TGF $\beta$ tumor suppressor activity $[38,49]$, thus providing a mechanism for retention of the capability of forming an invasive cancer at the primary site despite TGF $\beta$ activity generated by ectopic expression of the TGF $\beta$ RII.

Activation of inappropriate survival mechanisms such as survivin/XIAP and/or inactivation of tumor suppressors (i.e., TGF $\beta$ ) are involved in promoting cell survival during tumorigenicity and metastasis. The ability of malignant cells to withstand environmental stress is considered an important factor in tumor development and progression [1] as well as in the metastatic process [4]. Loss of TGF $\beta$-mediated apoptosis may contribute to tumor progression and metastasis under such stress conditions. Mehlen and Puisieux [4] and Giampieri et al., [50] have reviewed the particular importance of aberrant cell survival in the establishment of metastatic colonies in the foreign microenvironment of organs distal to the primary tumor site. Moreover, different stages of the metastatic process show different mechanisms for aberrant survival. We have shown that abrogation of autocrine TGF $\beta$ enables increased PI3K/AKT activation in
FET $\alpha$-DN cells under GFDS, which shifts the balance of signaling during stress by these cells from apoptosis to survival thus contributing to resistance to stress induced apoptosis.

The significance of survivin subcellular localization in cell survival has been addressed by the Altieri laboratory [46]. Nuclear survivin is associated with proliferation while cytoplasmic survivin is associated with cell survival [51]. Survivin associates with another IAP family member, XIAP, in response to cell death stimuli [27]. The resultant survivin-XIAP complex promotes increased XIAP stability from ubiquitination and subsequent proteosomal degradation [26]. Tumor cells have high pools of survivin present between the mitochondrial membranes that are released into the cytosol upon stress stimulation [28]. It was shown that when cytoplasmic survivin is not phosphorylated at S20 it binds XIAP and enhances XIAP stability by protecting it from proteasomal degradation thus enabling antagonization of apoptosome-mediated cell death through the ability of XIAP to inhibit caspase $-3,-7$ and -9 activation in vivo [26]. A recent study has documented that nuclear survivin has reduced stability and is not cytoprotective [52]. Our study shows for the first time that abrogation of TGF $\beta$ signaling results in enhanced cytosolic localization of survivin and XIAP proteins which are associated with enhanced cell survival capability and eventual metastasis in the FET colon cancer cell model (Figure 4A). This observation was further validated by restoring TGF $\beta$ sensitivity in the native CBS colon carcinoma cell line (Figure 6).

We have utilized genetic modification of TGF $\beta$ receptors to show that TGF $\beta$ receptor mediated signaling is critical to the suppression of metastasis in the FET and CBS colon cancer models. The question arises as to the potential breadth of cancers in which TGF $\beta$ receptor modulation would be a factor and whether pharmacological modulation would be possible. Over the past 15 years we and others have shown that transcriptional repression of either RI or RII is seen in a variety of histological types of cancer including colon, breast, lung and pancreatic cells lines [7-9,53-56]. Along this line, several clinical studies have indicated that cancer progression is associated with loss of TGF $\beta$ receptors in types of cancers where TGF $\beta$ mutation is rare or in the case of colon cancer, in patient samples without microsatellite instability thereby implying a lack of mutation [57-62]. More recently, we have shown that cancer cell lines with TGF $\beta$ receptor repression due to histone acetylation can be rescued by treatment with a clinical HDAC inhibitor candidate. Importantly, this pharmacological rescue results in TGF $\beta$ signaling dependent induction of apoptosis through disruption of survivin/XIAP mediated cell survival as seen both in vitro and in vivo in the 2 cell 
lines studied here as well as a pancreatic cancer cell line and 3 breast cancer cell lines [63]. Consequently, based on the broad range of cell lines showing TGF $\beta$ receptor repression, the clinical studies of cancer progression related to TGF $\beta$ receptor loss in cancers that rarely show TGF $\beta$ receptor mutations and the pharmacological responses of cell lines demonstrating TGF $\beta$ receptor transcriptional repression, the subset of cancers in which TGF $\beta$ receptor signaling potentially enables metastasis appears to be significant in a subset of cancers. Moreover, the mechanism of TGF $\beta$ receptor repression may be susceptible to pharmacological intervention [63].

This dichotomous role of TGF $\beta$ signaling with respect to tumor progression is problematic for strategies to target aberrant TGF $\beta$ signaling in cancer. The observations presented here raise the concern that abrogation of TGF $\beta$ signaling may lead to acceleration of malignant progression even in the biological context of invasive cancer. However, reconstitution of deficient TGF $\beta$ signaling can result in the direct activation of cell death and inhibition of metastasis thus indicating TGF $\beta$ is a metastatic suppressor in fully invasive carcinomas, thus indicating that at least in some cancer contexts the concept of enhancing TGF $\beta$ activity and/or the mechanisms by which TGF $\beta$ generates cell death could be of therapeutic value in highly progressed cancers.

\section{Conclusion}

The observations presented here indicate a metastasis suppressor role for TGF $\beta$ signaling in human colon cancer cells. This raises the concern that therapies targeting inhibition of TGF $\beta$ signaling may be imprudent in some patient populations with residual TGF $\beta$ tumor suppressor activity where consideration of enhancement of TGF $\beta$ signaling may be beneficial.

\section{Additional file}

Additional file 1: Abrogation of TGF $\beta$ signaling. (a) FETa and FETaDN cells in log phase growth were treated with varying concentrations of TGF $\beta[0,5,10 \mathrm{ng} / \mathrm{mL}]$ for $2 \mathrm{~h}$ followed by immunoblot analysis performed for pSmad2 and total Smad2 used as a loading control. (B) FETa and FETa-DN cells in log phase growth were treated with 0 or $5 \mathrm{ng} / \mathrm{mL}$ TGF $\beta$ for 48 hours followed by $\left[{ }^{3} \mathrm{H}\right]$ thymidine labeling to assess growth inhibition.

\section{Competing interests}

The authors declare that they have no competing interest.

\section{Author's contribution}

NS involved in experimental design, performed in vitro assays and IHC assays and drafted manuscript. AR performed in vivo orthotopic implantation experiments. ES performed histological slide preparation, histology assays and statistical analysis. MO performed in vivo orthotopic implantation experiments. CT performed tissue culture. JW participated in experimental design and data interpretation. MGB involved in experimental design, data interpretation, manuscript revision. All authors read and approved the final manuscript.

\section{Acknowledgements}

This work was supported by NCl grants CA38173, 54807, 72001, 34432 and T32-CA036727.

\section{Author details}

'Eppley Institute for Research in Cancer and Allied Diseases, University at Nebraska Medical Center, Omaha, USA. ${ }^{2}$ Department of Surgery, Division of Surgical Oncology, University of New Mexico, Albuquerque, USA.

${ }^{3}$ Department of Pharmacology and Therapeutics, Roswell Park Cancer Institute, Buffalo, USA. ${ }^{4}$ Department of Surgery, University at Buffalo, Buffalo, USA.

Received: 20 February 2012 Accepted: 18 May 2012

Published: 6 June 2012

\section{References}

1. Hanahan D, Weinberg RA: The hallmarks of cancer. Cell 2000, 100:57-70.

2. Chiang AC, Massague J: Molecular basis of metastasis. N Engl J Med 2008, 359:2814-2823.

3. Huerta S, Goulet EJ, Livingston EH: Colon cancer and apoptosis. Am I Surg 2006, 191:517-526.

4. Mehlen P, Puisieux A: (2006) Metastasis: a question of life or death. Nat Rev Cancer 2006, 6:449-458.

5. Bierie B, Moses HL: TGF-beta and cancer. Cytokine Growth Factor Rev 2006, 17:29-40.

6. Markowitz S, Wang J, Myeroff L, Parsons R, Sun L, Lutterbaugh J, Fan RS, Zborowska E, Kinzler KW, Vogelstein B: Inactivation of the type II TGF-beta receptor in colon cancer cells with microsatellite instability. Science 1995, 268:1336-1338.

7. Ammanamanchi $\mathrm{S}$, Brattain MG: Sp3 is a transcriptional repressor of transforming growth factor-beta receptors. J Biol Chem 2001, 276:3348-3352.

8. Ammanamanchi S, Freeman JW, Brattain MG: Acetylated sp3 is a transcriptional activator. J Biol Chem 2003, 278:35775-35780.

9. Ammanamanchi S, Brattain MG: Restoration of transforming growth factor-beta signaling through receptor RI induction by histone deacetylase activity inhibition in breast cancer cells. J Biol Chem 2004, 279:32620-32625.

10. Ahmed MM, Alcock RA, Chendil D, Dey S, Das A, Venkatasubbarao K Mohiuddin M, Sun L, Strodel WE, Freeman JW: Restoration of transforming growth factor-beta signaling enhances radiosensitivity by altering the Bcl-2/Bax ratio in the p53 mutant pancreatic cancer cell line MIA PaCa-2. J Biol Chem 2002, 277:2234-2246.

11. Freeman JW, DeArmond D, Lake M, Huang W, Venkatasubbarao K, Zhao S: Alterations of cell signaling pathways in pancreatic cancer. Front Biosci 2004, 9:889-898.

12. Hasegawa Y, Takanashi S, Kanehira Y, Tsushima T, Imai T, Okumura K: Transforming growth factor-beta1 level correlates with angiogenesis, tumor progression, and prognosis in patients with nonsmall cell lung carcinoma. Cancer 2001, 91:64-971.

13. Saito H, Tsujitani S, Oka S, Kondo A, Ikeguchi M, Maeta M, Kaibara N: The expression of transforming growth factor-beta1 is significantly correlated with the expression of vascular endothelial growth factor and poor prognosis of patients with advanced gastric carcinoma. Cancer 1999, 86:1455-1462.

14. Tsushima H, Kawata S, Tamura S, Ito N, Shirai Y, Kiso S, Imai Y, Shimomukai H, Nomura $Y$, Matsuda $Y$, Matsuzawa $Y$ : High levels of transforming growth factor beta 1 in patients with colorectal cancer: association with disease progression. Gastroenterology 1996, 110:375-382.

15. Jakowlew SB: Transforming growth factor-beta in cancer and metastasis. Cancer Metastasis Rev 2006, 25:435-457.

16. Wang J, Yang L, Yang J, Kuropatwinski K, Wang W, Liu XQ, Hauser J, Brattain MG: Transforming growth factor beta induces apoptosis through repressing the phosphoinositide 3-kinase/AKT/survivin pathway in colon cancer cells. Cancer Res 2008, 68:3152-3160.

17. Vivanco I, Sawyers CL: The phosphatidylinositol 3-Kinase AKT pathway in human cancer. Nat Rev Cancer 2002, 2:489-501.

18. Andersen MH, Svane IM, Becker JC, Straten PT: The universal character of the tumor-associated antigen survivin. Clin Cancer Res 2007, 13:5991-5994.

19. Montorsi M, Maggioni M, Falleni M, Pellegrini C, Donadon M, Torzilli G, Santambrogio R, Spinoli A, Coggi G, Bosari S: Survivin gene expression in 
chronic liver disease and hepatocellular carcinoma. Hepatogastroenterology 2007, 54:2040-2044.

20. Yantiss RK, Goodarzi M, Zhou XK, Rennert H, Pirog EC, Banner BF, Chen YT: Clinical, pathologic, and molecular features of early-onset colorectal carcinoma. Am J Surg Pathol 2009, 33:572-582

21. Ambrosini G, Adida C, Altieri DC: A novel anti-apoptosis gene, survivin, expressed in cancer and lymphoma. Nat Med 1997, 3:917-921.

22. Kawasaki H, Altieri DC, Lu CD, Toyoda M, Tenjo T, Tanigawa N: Inhibition of apoptosis by survivin predicts shorter survival rates in colorectal cancer. Cancer Res 1998, 58:5071-5074.

23. Miller M, Smith D, Windsor A, Kessling A: Survivin gene expression and prognosis in recurrent colorectal cancer. Gut 2001, 48:137-138.

24. Tanaka K, Iwamoto S, Gon G, Nohara T, Iwamoto M, Tanigawa N: Expression of survivin and its relationship to loss of apoptosis in breast carcinomas. Clin Cancer Res 2000, 6:127-134

25. Monzo M, Rosell R, Felip E, Astudillo J, Sanchez JJ, Maestre J, Martin C, Font A, Barnadas A, Abad A: A novel anti-apoptosis gene: re-expression of survivin messenger RNA as a prognosis marker in non-small-cell lung cancers. J. Clin. Onco. 1999, 17:2100-2104.

26. Dohi T, Xia F, Altieri DC: Compartmentalized phosphorylation of IAP by protein kinase A regulates cytoprotection. Mol Cell 2007, 27:17-28.

27. Dohi T, Okada K, Xia F, Wilford CE, Samuel T, Welsh K, Marusawa H, Zou H, Armstrong R, Matsuzawa D, Salvesten GS, Reed JC, Altieri DC: An IAP-IAP complex inhibits apoptosis. J Biol Chem 2004, 279:34087-34090.

28. Dohi T, Beltrami E, Wall NR, Plescia J, Altieri DC: Mitochondrial survivin inhibits apoptosis and promotes tumorigenesis. J Clin Invest 2004, 114:1117-1127.

29. Dan HC, Sun M, Kaneko S, Feldman RI, Nicosia SV, Wang HG, Tsang BK, Cheng JQ: Akt phosphorylation and stabilization of X-linked inhibitor of apoptosis protein (XIAP). J Biol Chem 2004, 279:5405-5412.

30. Awwad RA, Sergina N, Yang H, Ziober B, Willson JK, Zborowska E, Humphrey LE, Fan R, Ko TC, Brattain MG, Howell GM: The role of transforming growth factor alpha in determining growth factor independence. Cancer Res 2003, 63(15):4731-4738.

31. Howell GM, Humphrey LE, Awwad RA, Wang D, Koterba A, Periyasamy B, Yang J, Li W, Willson JK, Ziober BL, Coleman K, Carboni J, Lynch M, Brattain MG: Aberrant regulation of transforming growth factor-alpha during the establishment of growth arrest and quiescence of growth factor independent cells. J Biol Chem 1998, 273(15):9214-9223.

32. Ongchin M, Sharratt E, Dominguez I, Simms N, Wang J, Cheney R, LeVea C, Brattain MG, Rajput A: The effects of epidermal growth factor receptor activation and attenuation of the TGFbeta pathway in an orthotopic model of colon cancer. J Surg Res 2009, 156:250-256.

33. Rajput A, Koterba AP, Kreisberg JI, Foster JM, Willson JK, Brattain MG: A novel mechanism of resistance to epidermal growth factor receptor antagonism in vivo. Cancer Res 2007, 67:665-673.

34. Zhou Y, Brattain MG: Synergy of epidermal growth factor receptor kinase inhibitor AG1478 and ErbB2 kinase inhibitor AG879 in human colon carcinoma cells is associated with induction of apoptosis. Cancer Res 2005, 65(13):5848-5856.

35. Chantret I, Barbat A, Dussaulx E, Brattain MG, Zweibaum A: Epithelial polarity, villin expression, and enterocytic differentiation of cultured human colon carcinoma cells: a survey of twenty cell lines. Cancer Res 1998, 48:1936-1942.

36. Jiang D, Yang H, Willson JK, Liang J, Humphrey LE, Zborowska E, Wang D, Foster J, Fan R, Brattain MG: Autocrine transforming growth factor alpha provides a growth advantage to malignant cells by facilitating re-entry into the cell cycle from suboptimal growth states. J Biol Chem 1998, 273:31471-31479.

37. Wood CB, Gillis CR, Hole D, Malcom AJ, Blumgart LH: Local tumour invasion as a prognostic factor in colorectal cancer. Brit. Jour. of Surg. 1981, 68:326-328.

38. Ye SC, Foster JM, Li W, Liang J, Zborowska E, Venkateswarlu S, Gong J, Brattain MG: Contextual effects of transforming growth factor beta on the tumorigenicity of human colon carcinoma cells. Cancer Res 1999, 59:4725-4731.

39. Sharkey RM, Primus FJ, Goldenberg DM: Comparison of the sensitivity of the indirect, antibody-conjugated and the triple-bridge immunoperoxidase methods for immunohistochemical detection of carcinoembryonic antigen. Histochemistry 1980, 66:35-42.

40. Rajput A, Dominguez I, Rose R, Beko A, Levea C, Sharratt E, Mazurchuk R, Hoffman RM, Brattain MG, Wang J: Characterization of HCT116 human colon cancer cells in an orthotopic model. J Surg Res 2008, 147:276-281.
41. Guo XN, Rajput A, Rose R, Hauser J, Beko A, Kuropatwinski K, LeVea C, Hoffman RM, Brattain MG, Wang J: Mutant PIK3CA-bearing colon cancer cells display increased metastasis in an orthotopic model. Cancer Res 2007, 67:5851-5858.

42. Wang J, Rajput A, Kan JL, Rose R, Liu XQ, Kuropatwinski K, Hauser J, Beko A, Dominquez I, Sharratt EA, Brattain L, Levea C, Sun FL, Keane DM, Gibson NW, Brattain MG: Knockdown of Ron kinase inhibits mutant phosphatidylinositol 3-kinase and reduces metastasis in human colon carcinoma. Jour. of Biol. Chem. 2009, 284:10912-10922.

43. Endl E, Hollmann C, Gerdes J: Antibodies against the Ki-67 protein: assessment of the growth fraction and tools for cell cycle analysis. Methods Cell Biol 2001, 63:399-418.

44. Gavrieli Y, Sherman Y, Ben-Sasson SA: Identification of programmed cell death in situ via specific labeling of nuclear DNA fragmentation. J Cell Biol 1992, 119:493-501.

45. Hayashi K, Tanaka M, Shimada T, Miwa M, Sugimura T: Size and shape of poly (ADP-ribose): examination by gel filtration, gel electrophoresis and electron microscopy. Biochem Biophys Res Commun 1983, 112:102-107.

46. Altieri DC: New wirings in the survivin networks. Oncogene 2008, 27:6276-6284

47. Padua D, Zhang XH, Wang Q, Nadal C, Gerald WL, Gomis RR, Massague J: TGFbeta primes breast tumors for lung metastasis seeding through angiopoietin-like 4. Cell 2007, 133:66-77.

48. Welm AL: TGFbeta primes breast tumor cells for metastasis. Cell 2008 , 133:27-28.

49. Hu YP, Patil SB, Panasiewicz M, Li W, Hauser J, Humphrey LE, Brattain MG: Heterogeneity of receptor function in colon carcinoma cells determined by cross-talk between type I insulin-like growth factor receptor and epidermal growth factor receptor. Cancer Res 2008, 68:8004-8013.

50. Giampieri S, Manning C, Hooper S, Jones L, Hill CS, Sahai E: Localized and reversible TGFbeta signalling switches breast cancer cells from cohesive to single cell motility. Nat Cell Biol 2009, 11:1281-1284.

51. Li F, Yang J, Ramnath N, Javle MM, Tan D: Nuclear or cytoplasmic expression of survivin: what is the significance? Int J Cancer 2005, 114:509-512.

52. Connell CM, Colnaghi R, Wheatley SP: Nuclear survivin has reduced stability and is not cytoprotective. J Biol Chem 2008, 283:3289-3296.

53. Ammanamanchi S, Kim SJ, Sun LZ, Brattain MG: Induction of transforming growth factor-beta receptor type II expression in estrogen receptorpositive breast cancer cells through SP1 activation by 5-aza-2'deoxycytidine. J Biol Chem 1998, 273:16527-16534.

54. Ammanamanchi S, Brattain MG: 5-azaC treatment enhances expression of transforming growth factor-beta receptors through down-regulation of Sp3. J Biol Chem 2001, 276:32854-32859.

55. Venkatasubbarao K, Ammanamanchi S, Brattain MG, Mimari D, Freeman JW: Reversion of transcriptional repression of Sp1 by 5 aza-2' deoxycytidine restores TGF-beta type II receptor expression in the pancreatic cancer cell line MIA PaCa-2. Cancer Res 2001, 61:6239-6247.

56. Huang W, Zhao S, Ammanamanchi S, Brattain M, Venkatasubbarao K, Freeman JW: Trichostatin A induces transforming growth factor beta type II receptor promoter activity and acetylation of Sp1 by recruitment of PCAF/p300 to a Sp1.NF-Y complex. J Biol Chem 2005, 280:10047-10054.

57. Gobbi H, Arteaga CL, Jensen RA, Simpson JF, Dupont WD, Olson SJ, Schuyler PA, Plummer WD Jr, Page DL: Loss of expression of transforming growth factor beta type II receptor correlates with high tumour grade in human breast in-situ and invasive carcinomas. Histopath 2000, 36:168-177.

58. Matsushita MK, Matsuzaki M, Date T, Watanabe K, Shibano T, Nakagawa S, Yaanagitani Y, Amoh H, Takemoto N, Ogata C, Yamamoto Y, Kubota T, Seki H, Inokuchi M, Nishizawa H, Takada T, Sawamura A, Inoue O, Inoue K: Downregulation of TGF-beta receptors in human colorectal cancer: implications of cancer development. Br J Cancer 1999, 80:194-205.

59. Borczuk AC, Kim HK, Yegen HA, Friedman RA, Powell CA: Lung adenocarcinoma global profiling identifies type II transforming growth factor-beta receptor as a represser of invasiveness. Am J Respir Crit Care Med 2005, 172:729-737.

60. Kim IY, Ahn HJ, Zerlner DJ, Shaw JW, Lang S, Kato M, Oefelein MG, Miyazono K, Nemeth JA, Kozlowski JM, Lee C: Loss of expression of transforming growth factor beta type I and type II receptors correlates with tumor grade in human prostate cancer tissues. Clin Cancer Res 1996, 1996(8):1255-1261.

61. Gobbi H, Dupont WD, Simpson JF, Plummer WD Jr, Schuyler PA, Olson SJ, Arteaga CL, Page DL: Transforming growth factor-beta and breast cancer risk in women with mammary epithelial hyperplasia. J Natl Can Inst 1999, 91:2096-2101 
62. Buck MB, Fritz P, Dippon J, Zugmaer G, Knabbe C: Prognostic significance of transforming growth factor beta receptor II in estrogen receptornegative breast cancer patients. Clin. Can. Res. 2004, 10:491-498.

63. Chowdhury S, Howell GM, Teggart CA, Chowdhury A, Person JJ, Bowers DM, Brattain MG: Histone deacetylase inhibitor belinostat represses survivin expression through reactivation of transforming growth factor beta (TGFbeta) receptor II leading to cancer cell death. J Biol Chem 2011, 286:30937-30948.

doi:10.1186/1471-2407-12-221

Cite this article as: Simms et al:: Transforming growth factor- $\beta$

suppresses metastasis in a subset of human colon carcinoma cells. BMC

Cancer 2012 12:221

\section{Submit your next manuscript to BioMed Central and take full advantage of:}

- Convenient online submission

- Thorough peer review

- No space constraints or color figure charges

- Immediate publication on acceptance

- Inclusion in PubMed, CAS, Scopus and Google Scholar

- Research which is freely available for redistribution 